\title{
STRATEGIES FOR SMEs DURING ECONOMIC CRISIS
}

Tirupathi Anand, SP Jain School of Global Management, Dubai U.A.E. Arindam Banerjee, SP Jain School of Global Management, Dubai U.A.E. Sadia Riaz, SP Jain School of Global Management, Dubai U.A.E.

\author{
dx.doi.org/10.18374/IJSM-20-1.6
}

\begin{abstract}
Small and Medium Enterprises (SME) are the backbone of any economy and play a vital role in the creation of employment and in providing the much-needed support to the large industries. All the ancillary and support services needed by large industries are provided by the SMEs. The business support for spare parts or components or logistics or services is mostly provided by the SMEs in most of the economies. However, when there is economic crisis the SMEs are the first to be affected as they are the most vulnerable. The SMEs suffer the most during any crisis situation and they also quickly swing back into action when the economy revives. This immediate and severe impact on the SME sector eventually leads to a roller coaster ride for the SME owners and managers which becomes very challenging to handle. The research scholar is looking at creating a set of strategies which could help the SMEs during economic crisis to survive and stay in business.
\end{abstract}

Keywords: Small and Medium Enterprises; Economic Crisis; Strategies; Business Model; Decision Making; Business Performance 